\title{
Damage behaviours of concrete and prediction models under the joint effect of freeze-thaw attack and ultraviolet radiation
}

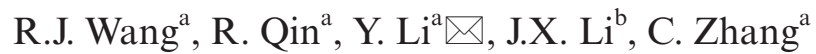 \\ a. State Key Laboratory of Eco-hydraulics in Northwest Arid Region of China, Xi'an University of Technology, (Xi'an, China) \\ b. College of Civil and Environmental Engineering, University of New South Wales, (Sydney, Australia) \\ $\triangle$ LY1990120311@163.com

\begin{abstract}
The study investigated the joint effect of freeze-thaw attack and ultraviolet (UV) radiation on concrete. Mass loss ratio, relative dynamic modulus of elasticity (RDME) and flexural strength of concrete were experimentally investigated. A two-way ANOVA was used to analyse the effect of UV radiation on the test results. Water-binder ratio significantly affected the mass loss ratio, RDME and flexural strength. Meanwhile, UV radiation only had a significant effect on mass loss ratio but had no evident effect on RDME and flexural strength. Concrete microstructure was demonstrated by microscopic analysis via scanning electron microscope to explore the insight into the damage evolution of concrete under the joint effect. Prediction models of the damage degree of concrete were proposed by incorporating the results in this investigation. Comparison results showed that the prediction values were consistent with the experimental values.
\end{abstract}

KEYWORDS: Concrete; Freezing/thawing; Scanning Electron Microscopy (SEM); Durability; Flexural strength

Citation/Citar como: Wang, R.J.; Qin, R.; Li, Y.; Li, J.X.; Zhang, C. (2019) Damage behaviours of concrete and prediction models under the joint effect of freeze-thaw attack and ultraviolet radiation. Mater. Construcc. 69 [335], e198 https://doi.org/10.3989/mc.2019.12018

RESUMEN: Comportamientos de daños de hormigón y modelos de predicción bajo el efecto conjunto del ataque hielo-deshielo y la radiación ultravioleta. Se analiza la relación, en hormigones, del efecto conjunto del ataque hielo-deshielo y la radiación ultravioleta en función de sus parámetros de Pérdida de Masa (PM), Módulo Dinámico de Elasticidad (MDRE) y Resistencia a la Flexión, a partir del tratamiento estadístico de los resultados (ANOVA). Se ha constatado que la proporción agua/cemento (o aglomerante) (w/c) influyó significativamente sobre la Pérdida de Masa (PM), MDRE y Resistencia a la Flexión. La radiación UV, tuvo un efecto significativo sobre PM pero apenas en los otros dos parámetros analizados. La evolución del deterioro en el hormigón se evaluó estudiando su microestructura a partir de Microscopía Electrónica de Barrido de Electrones Secundarios (MEB-SSE). A partir de esta investigación se propuso un modelo predictivo del grado de deterioro del hormigón, concluyéndose que los datos de predicción tenían una buena relación con los datos experimentales encontrados.

PALABRAS CLAVE: Hormigón; Hielo/deshielo; Microscopía Electrónica de Barrido (MEB); Durabilidad; Resistencia a la flexión

ORCID ID: R.J. Wang (https://orcid.org/0000-0002-4421-6765); R. Qin (https://orcid.org/0000-0003-0343-1167); Y. Li (https://orcid.org/0000-0002-6001-758X); J.X. Li (https://orcid.org/0000-0002-4489-5489); C. Zhang (https://orcid. org/0000-0002-0865-3191).

Copyright: (C) 2019 CSIC. This is an open-access article distributed under the terms of the Creative Commons Attribution License (CC BY) Spain 4.0. 


\section{INTRODUCTION}

Material deteriorations caused by durability do not have immediate safety issues; however, they progressively lead to structural damage that places a potential danger to structures (1). In cold areas, freeze-thaw (F-T) attack is one of the most significant factors that leads to concrete deterioration. Moreover, F-T attack influences the lifespan of concrete structures. Researchers have conducted in-depth studies on the frost resistance durability of concrete. Moreover, two essential damages have been considered-surface stripping and internal damage. The former is caused by the freezing of water in concrete surface, thereby resulting in weight loss and reduced concrete cover. The latter is caused by the frosting of internal moisture within concrete pores. In addition, the primary effects of internal damage are the generation and disintegration of microcracks (2). Once internal damage is formed and developed, concrete properties (i.e. elasticity modulus, compressive strength and tensile strength) deteriorate (3).

Scholars have explored the frost damage mechanism, and several theories have been proposed (4-6). With the development of theoretical research, experimental studies on the frost resistance of concrete have been developed, and great progress has been achieved (3, 7-10). However, concrete structures may not be attacked by $\mathrm{F}-\mathrm{T}$ alone. Other factors (e.g. sulphate attack, chloride attack, fatigue load and ultraviolet (UV) radiation) combined with $\mathrm{F}-\mathrm{T}$ attack reduce concrete properties. Therefore, considering $\mathrm{F}-\mathrm{T}$ attack alone is unreasonable. Consequently, several researchers have conducted different studies to investigate joint attacks on concrete.

Li et al. (11) investigated the effects of the combined action of $\mathrm{F}-\mathrm{T}$ cycles and sulphate attack on concrete resistance. They confirmed that sulphate solution produces combined positive and negative effects on concrete subjected to F-T cycles. Moreover, their results are consistent with those of Wang et al. (12). Yang et al. (13) studied the effects of sulphate attack and F-T cycle alternation on concrete microstructure. Their results revealed that $\mathrm{F}-\mathrm{T}$ damage is a major effective factor. Wang and Niu (14) investigated the durability of frost and sulphate resistance of ordinary concrete. They also accelerated shotcrete with and without steel fibre. They concluded that ordinary shotcrete is more durable than ordinary concrete under the action of F-T cycles and sulphate attack. Moreover, steel fibre-reinforced shotcrete shows the best durability under the same condition. Piasta et al. (15) reported that the F-T resistance of air-entrained mortars subjected to the initial sulphate attack is significantly reduced and is comparable with that of non-air-entrained cement mortars. The reduced frost resistance is caused by ettringite filling the air voids.

Tian et al. (16) conducted a test joint effect of flexural load and salt F-T cycles. They also proposed a prediction model of damage degree. This model shows good consistency with the values in their investigation. Kosior-Kazberuk and Berkowski (17) studied the surface-scaling resistance under the combined F-T cycles, sodium chloride solution and flexural load. Their results showed that the combined attack accelerates the surface scaling of concrete. Diao et al. (18) reported that if F-T cycles and mixed corrosion are combined with persistent loading, then a rapid drop in strength and deformation capacity of reinforced concrete beams can be identified. Enfedaque et al. (19) indicated that after 4, 14 and $28 \mathrm{~F}-\mathrm{T}$ cycles, the fracture energy of concrete with an air-entraining additive slightly increases. $\mathrm{Lu}$ et al. (20) found that fatigue loading history accelerates strength reduction.

Wang et al. (21) studied the combined effects of F-T cycling and chloride on rebar corrosion in concrete. Their results indicated that the factors correlated with increased risk of rebar corrosion in concrete rapidly increase with the number of $\mathrm{F}-\mathrm{T}$ cycles. Jacobsen et al. (22) reported that internal cracking caused by frost action increases the chloride penetration rate by a factor of $2.5-8$. Zhang et al. (23) studied the effects of F-T cycles on chloride penetration into concrete. They found that $\mathrm{F}-\mathrm{T}$ damage significantly influences chloride ingress in concrete.

Kuosa et al. (24) investigated the manner in which internal F-T damage affects carbonation. They found that the depth of carbonation increases from $3.5 \mathrm{~mm}$ to approximately $5.5 \mathrm{~mm}$ as the $\mathrm{F}-\mathrm{T}$ deterioration measured by relative dynamic modulus of elasticity (RDME) increases from $80 \%-30 \%$. He et al. (25) reported that the damage caused by alternative $\mathrm{F}-\mathrm{T}$ attacks and carbonation on concrete is more severe than that by any of their single attack. Liu et al. (26) developed two types of experiment, that is, $\mathrm{F}-\mathrm{T}$ cycles subjected to sulphate $(\mathrm{SF})$ and those subjected to sulphate and carbonation (SFC). They reported that specimens under SFC are more severely damaged than those under SF.

In 2011, investigations at several plateau regions in China have shown that concrete damage in plateau regions is worse than in plain regions (27). As typical climatic features in plateau regions, F-T attack, low air pressure and UV radiation intensify the destructive effect on concrete. Few investigations have been performed regarding concrete durability in plateau regions. However, to the best of the authors' knowledge, the effects of the combined action of $\mathrm{F}-\mathrm{T}$ cycles and UV radiation on concrete resistance have been rarely studied via experiments. Therefore, this study aims to evaluate concrete resistance to the combined F-T attack and UV radiation. In this 
study, mass loss ratio and RDME were selected as degradation indexes. Furthermore, the effect of UV radiation on the flexural strength of concrete after F-T cycles was investigated. Finally, concrete microstructure was characterised via scanning electron microscopy (SEM).

\section{MATERIALS AND METHODS}

\subsection{Materials and mixture proportions}

The cement used for practical experimentation was $42.5 \mathrm{R}$ general-use Portland cement. Crushed granite with nominal particle sizes of $5 \mathrm{~mm}-40 \mathrm{~mm}$ and Weihe river sand with a fineness modulus of 2.35 were used as the coarse and fine aggregates, respectively. The dosage of Grade $\Pi$ fly ash used was $20 \%$ by mass of binder. The air-entraining agents (AEAs) and the superplasticiser (SP) with a waterreducing rate of $20 \%$ by weight were used in the concrete mixtures. Table 1 lists the detailed properties of sand and coarse aggregates.

Three concrete mixtures were developed with water-binder $(\mathrm{w}-\mathrm{b})$ ratios of $0.35,0.40$ and 0.45 . A total water content of $129 \mathrm{~kg} / \mathrm{m}^{3}$ was used. Table 2 presents the details of mix proportions and the concrete properties.

\subsection{Mixing procedures}

All specimens were cured under the standard curing condition. The preparation steps for concrete material are as follows. (i) Add cement, fly ash, gravel and sand into the concrete mixer and mix for $30 \mathrm{~s}$. (ii) Add water together with the given concrete admixture and mix for 3 min. (iii) Pour the fresh concrete into steel moulds and then vibrate for $30 \mathrm{~s}$ on the vibrating table. (iv) Cure each specimen under $20^{\circ} \mathrm{C}$ and $95 \%$ relative humidity.

TABLE 1. Properties of aggregates

\begin{tabular}{lccc}
\hline & $\begin{array}{c}\text { Water } \\
\text { absorption } \\
(\mathbf{\%})\end{array}$ & $\begin{array}{c}\text { Loose bulk } \\
\mathbf{d e n s i t y} \\
\left(\mathbf{k g} / \mathbf{m}^{3}\right)\end{array}$ & $\begin{array}{c}\text { Apparent } \\
\text { density } \\
\left(\mathbf{k g} / \mathbf{m}^{3}\right)\end{array}$ \\
\hline Sand & 0.79 & 1675 & 2593 \\
Coarse aggregates & 0.76 & 1426 & 2665 \\
\hline
\end{tabular}

\subsection{Experimental procedures}

UV radiation is intense at high elevations. For example, UV radiation can reach $356-444 \mathrm{MJ} \cdot \mathrm{m}^{-2} \cdot \mathrm{a}^{-1}$ in Xinjiang, China. Therefore, the considered radiation intensity in this investigation was $365 \mathrm{MJ} \cdot \mathrm{m}^{-2} \cdot \mathrm{a}^{-1}$ (i.e. $1 \mathrm{MJ} \cdot \mathrm{m}^{-2} \cdot \mathrm{d}^{-1}$ ). In this test, UVA-340 UV lamps were selected to simulate UV radiation in sunlight due to their consistency with the UV spectrum of sunlight. The UV intensity of UVA-340 UV is $200 \mathrm{~W} \cdot \mathrm{m}^{-2}$, which can be calculated as follows [1]:

$$
T=T^{\prime}\left(\frac{L^{\prime}}{L}\right)^{2}
$$

where $T$ is the radiation intensity at $L$ from the lamps, $\mathrm{W} \cdot \mathrm{m}^{-2} ; T^{\prime}$ is the theoretical radiation intensity, $0.5 \mathrm{~W} \cdot \mathrm{m}^{-2} ; L$ is the distance from the surface of specimens to UV lamps, $0.05 \mathrm{~m}$; and $L$ ' is the distance corresponding to the theoretical intensity, $1 \mathrm{~m}$.

On the basis of $T$ calculated by Eq. [1], the value of UV radiation that can be calculated by Eq. [2] was $17.3 \mathrm{MJ} \cdot \mathrm{m}^{-2}$ per day in the test box (i.e. specimens exposed in the test box for 1 day is equal to 17.3 days under natural conditions).

$$
Q=T \times t
$$

where $Q$ is the UV radiation, $\mathrm{J} \cdot \mathrm{m}^{-2}$; and $t$ is the UV exposure time, $\mathrm{s}$.

The concrete was exposed to the UV radiation during the curing period and subjected to $\mathrm{F}-\mathrm{T}$ cycles during the operation period. On this basis, the specimens were UV-treated for 5 days (approximately 90 days under natural conditions) before the F-T test. Figure 1 illustrates the UV radiation equipment for achieving UV exposure.

In this study, six groups (three experimental groups and three control groups) of specimens were prepared. For the experimental groups $(\mathrm{A}(\mathrm{E}), \mathrm{B}(\mathrm{E})$ and $C(E)), 100 \mathrm{~mm} \times 100 \mathrm{~mm} \times 400 \mathrm{~mm}$ specimens were cured for 23 days and then UV-treated for 5 days. For the control groups $(\mathrm{A}(\mathrm{C}), \mathrm{B}(\mathrm{C})$ and $\mathrm{C}(\mathrm{C})$ ), the same specimens were cured for 28 days. The mass and initial transverse frequencies of the specimens were measured after curing or exposing to $\mathrm{UV}$ radiation.

\begin{tabular}{|c|c|c|c|c|c|c|c|c|c|c|}
\hline Group & $\begin{array}{l}\mathbf{w - b} \\
\text { ratio }\end{array}$ & $\begin{array}{c}\text { Water } \\
\left(\mathrm{kg} / \mathrm{m}^{3}\right)\end{array}$ & $\begin{array}{l}\text { Cement } \\
\left(\mathrm{kg} / \mathrm{m}^{3}\right)\end{array}$ & $\begin{array}{c}\text { Gravel } \\
\left(\mathrm{kg} / \mathrm{m}^{3}\right)\end{array}$ & $\begin{array}{c}\text { Sand } \\
\left(\mathrm{kg} / \mathrm{m}^{3}\right)\end{array}$ & $\begin{array}{c}\text { Fly ash } \\
(\%)\end{array}$ & $\begin{array}{c}\text { AEA } \\
(\%)\end{array}$ & $\begin{array}{l}\text { SP } \\
(\%)\end{array}$ & $\begin{array}{c}\text { Slump } \\
(\mathrm{mm})\end{array}$ & $\begin{array}{c}\mathbf{f}_{\mathrm{cm}, 28 \mathrm{~d}(10 \mathrm{~cm})} \\
(\mathrm{MPa})\end{array}$ \\
\hline A & 0.35 & 129 & 295 & 1234 & 691 & 20 & 0.03 & 1.0 & 45 & 48.77 \\
\hline B & 0.40 & 129 & 258 & 1251 & 716 & 20 & 0.03 & 1.0 & 54 & 41.90 \\
\hline $\mathrm{C}$ & 0.45 & 129 & 229 & 1261 & 738 & 20 & 0.03 & 1.0 & 65 & 33.82 \\
\hline
\end{tabular}

TABLE 2. Mixing proportions and concrete properties 


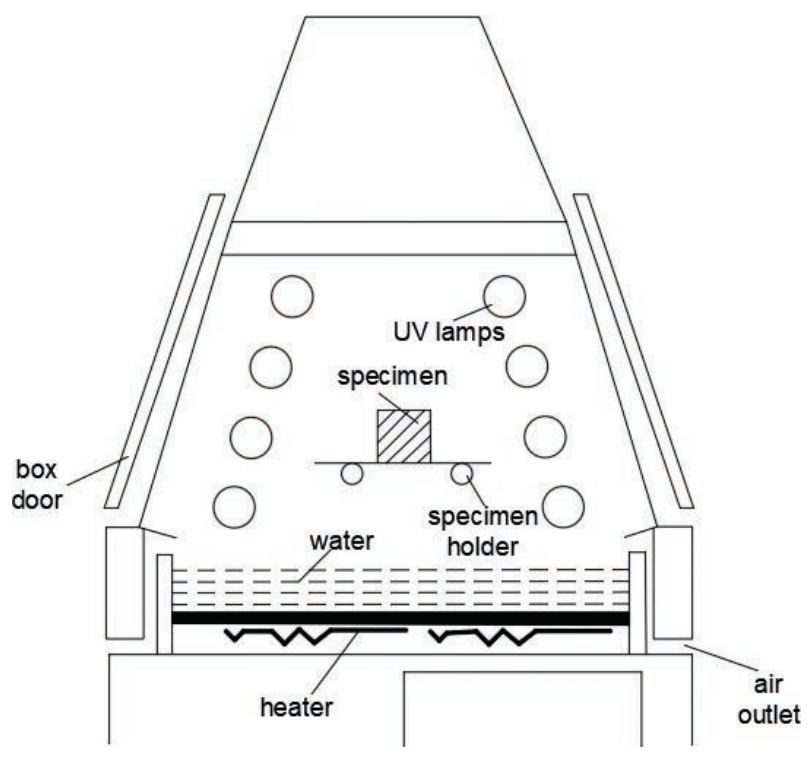

FIGURE 1. Schematic drawing of the UV radiation equipment.

Sequentially, a rapid $\mathrm{F}-\mathrm{T}$ test was conducted in an $\mathrm{F}-\mathrm{T}$ apparatus according to the Chinese standard GB/T50082-2009 (similar to ASTM C666/C666M-03). These specimens were immersed in clean water to investigate their frost resistance. Afterwards, they were placed in the F-T apparatus and subjected to $\mathrm{F}-\mathrm{T}$ cycles. In each cycle, the specimens were frozen at $5{ }^{\circ} \mathrm{C}$ to $-20{ }^{\circ} \mathrm{C}$ and thawed at $5^{\circ} \mathrm{C}$ for $4 \mathrm{~h}$. This process was repeated 275 times. Mass and initial transverse frequencies were measured to calculate mass loss ratio and RDME.

Finally, a flexural test was conducted to investigate the difference of flexural strength among groups. Figure 2 shows the loading equipment for bending loads.

\subsection{Analytical method}

Mass loss ratio and RDME were selected to measure the frost resistance of concrete. Both were calculated by using Eqs. [3] and [4], respectively.

$$
W=\frac{G_{0}-G_{n}}{G_{0}} \times 100
$$

where $W$ is the mass loss ratio at $n \mathrm{~F}-\mathrm{T}$ cycles, \%; $G_{n}$ is the mass after $n \mathrm{~F}-\mathrm{T}$ cycles, $\mathrm{N}$; and $G_{0}$ is the mass at the beginning of the F-T cycle test, $\mathrm{N}$.

$$
R D M E=\frac{f_{n}^{2}}{f_{0}^{2}} \times 100
$$

where $R D M E$ is the RDME at $n \mathrm{~F}-\mathrm{T}$ cycles, \%; $f_{n}$ is the initial transverse frequency at $n \mathrm{~F}-\mathrm{T}$ cycles,

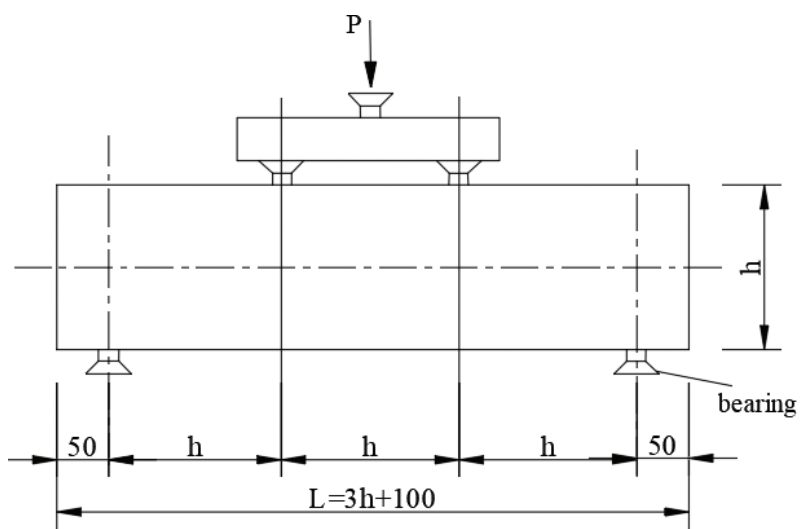

FIGURE 2. Schematic diagram of loading equipment.

$\mathrm{Hz}$; and $f_{0}$ is the initial transverse frequency at the beginning of the $\mathrm{F}-\mathrm{T}$ cycle test, $\mathrm{Hz}$.

To understand the significance level of UV radiation for the frost resistance of concrete, a two-way ANOVA was applied to analyse the effect of UV radiation on the test results.

For one-way ANOVA, three important measures of variability similar to regression theory were applied to test the population means (28).

$$
\begin{gathered}
S S T=\sum_{i=1}^{k} \sum_{j=1}^{n}\left(y_{i j}-\bar{y}_{.} .\right)^{2} \\
S S A=n \sum_{i=1}^{k}\left(\bar{y}_{i .}-\bar{y}_{. .}\right)^{2} \\
S S E=\sum_{i=1}^{k} \sum_{j=1}^{n}\left(y_{i j}-\bar{y}_{i} .\right)^{2}
\end{gathered}
$$

where $y_{i j}$ represents the $j$ th observation from the $i$ th treatment; $\bar{y}$. is the mean of all $n k$ observations ( $n$ : number of samples per treatment; $k$ : number of treatments); $\overline{y_{i}}$. is the mean of all observations in the sample from the $i$ th treatment; $S S T$ is the "total sum of squares'; $S S A$ is the 'treatment sum of squares'; and $S S E$ is the 'error sum of squares'.

The sum of squares can be conveniently identified by Eq. [8], which expresses how the betweentreatment $(S S A)$ and within-treatment $(S S E)$ variations added up to the total sum of squares.

$$
S S T=S S A+S S E
$$

For two-way ANOVA, Eqs. [5] and [8] can be directly used. However, Eqs. [6] and [7] must be modified to characterise the responses correctly (29). Specifically, the treatment (level) component of variance was broken down into sums of squares for each factor and can be calculated by Eq. [6]. The modified $S S A$ for two-way ANOVA is the sum of the separate sums of squares for each factor, and the 
modified $S S E$ can be deduced by Eq. [8] only if $S S A$ is replaced by modified $S S A$.

To quantify the idea of statistical significance of evidence, the significance of UV radiation for twoway ANOVA was determined on the basis of associated p-values. For the statistical significance level of all analyses, the p-value of 0.05 , which is mostly offered for experimental analysis, was selected (28). If the p-value was less than or equal to 0.05 , then the means of two or more independent groups were statistically significantly different from each other for the two-way analysis. Therefore, the null hypothesis that all the group population means of cooperation are equal was rejected. Otherwise (i.e. if the p-value is greater than 0.05), the means were not statistically significant. For convenience, F-ratio (i.e. ratio of between-group variability to within-group variability) was compared with $\mathrm{F}_{0.05}$ to determine whether the p-value was greater than 0.05 . If the F-ratio was greater than or equal to $\mathrm{F}_{0.05}$, then the $\mathrm{p}$-value was less than or equal to 0.05 . Otherwise, the p-value was greater than 0.05. Mean square represents an estimate of population variance. This estimate was calculated by dividing the corresponding sum of squares by the degrees of freedom (DF).

\section{RESULTS AND DISCUSSION}

\subsection{Surface scaling}

Specimens in group $\mathrm{C}(\mathrm{C})$ were selected to illustrate the surface changes of concrete specimens. Figures 3(a)-3(g) show the concrete deterioration in group $\mathrm{C}(\mathrm{C})$ under the cyclic F-T condition. The surface of concrete specimens significantly changed with the increase of F-T cycles. The surface mortar (a)

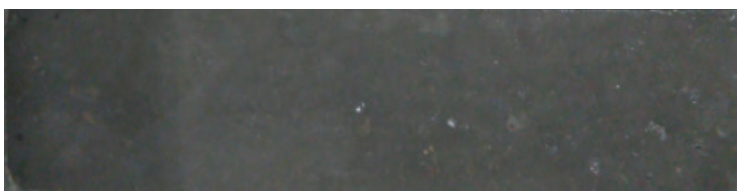

(c)

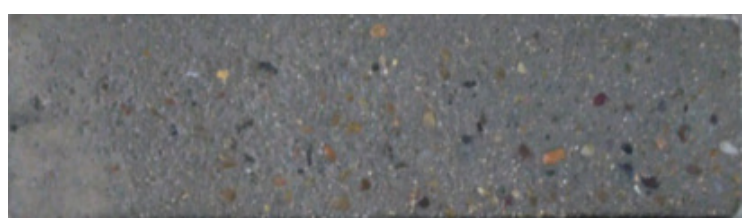

(e)



(g)

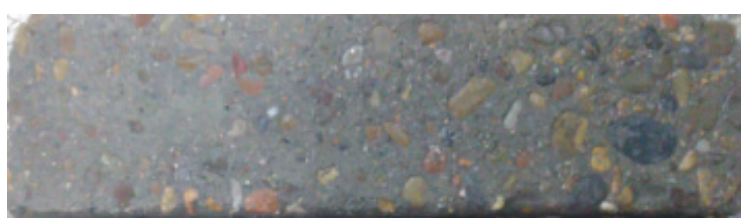

(i)

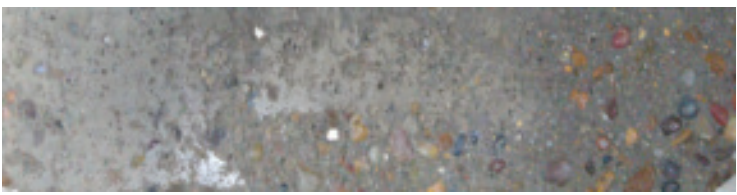

(k)

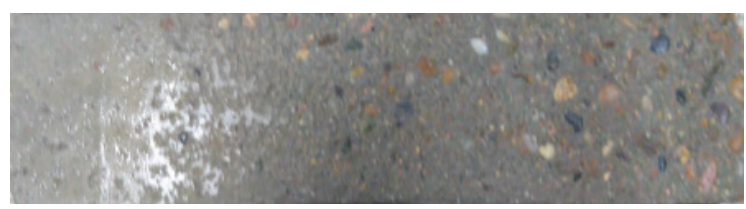

(b)

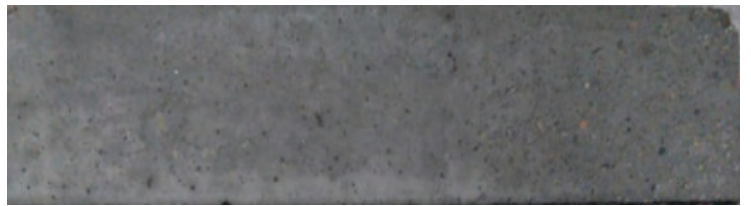

(d)

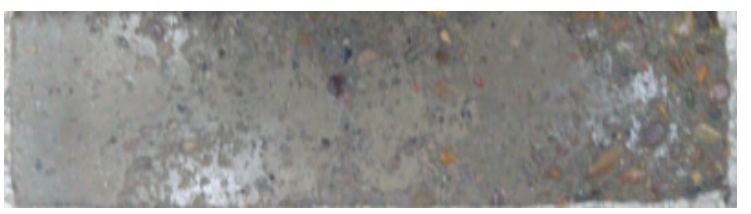

(f)

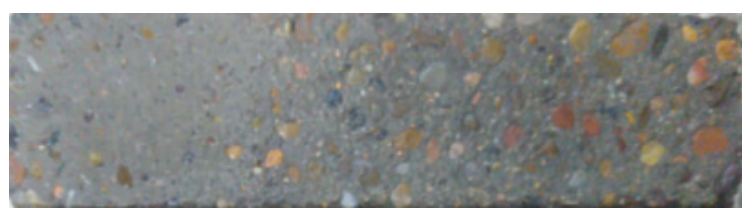

(h)

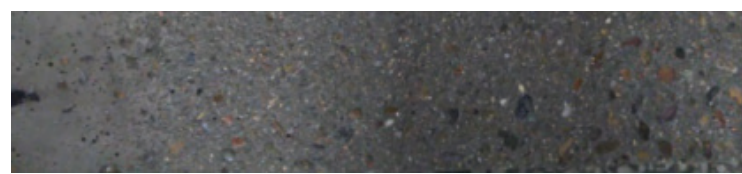

(j)

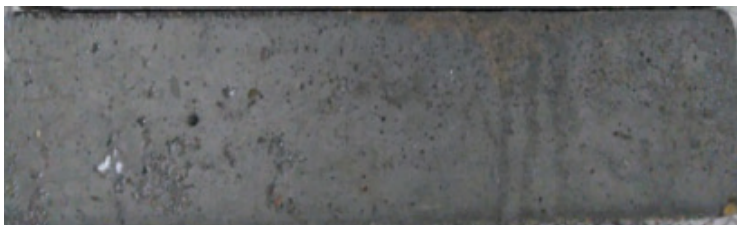

FIGURE 3. Deterioration of concrete specimens under the cyclic F-T condition. (a) $\mathrm{C}(\mathrm{C})$ at 0 cycle (b) $\mathrm{C}(\mathrm{C})$ at 50 cycles (c) $\mathrm{C}(\mathrm{C})$ at 100 cycles (d) $C(C)$ at 150 cycles (e) $C(C)$ at 200 cycles (f) $C(C)$ at 250 cycles (g) C(C) at 275 cycles (h) A(C) at 275 cycles (i) B(C) at 275 cycles $(\mathrm{j}) \mathrm{C}(\mathrm{E})$ at 50 cycles $(\mathrm{k}) \mathrm{C}(\mathrm{E})$ at 150 cycles. 
of specimens showed gradual stripping, and the coarse aggregates were exposed after 100 cycles. Thus, serious F-T damage occurred.

Specimens in groups $\mathrm{A}(\mathrm{C}), \mathrm{B}(\mathrm{C})$ and $\mathrm{C}(\mathrm{C})$ were selected to illustrate the influence of $\mathrm{w}-\mathrm{b}$ ratio on the frost resistance of concrete. As shown in Figures 3(g) 3(i), the surface damage of specimens in group $\mathrm{A}(\mathrm{C})$ with the lowest $\mathrm{w}-\mathrm{b}$ ratio $(0.35)$ was the lightest when subjected to $275 \mathrm{~F}-\mathrm{T}$ cycles. The surface damage of specimens in group $\mathrm{C}(\mathrm{C})$ with the highest $\mathrm{w}-\mathrm{b}$ ratio (0.45) was the most serious. Therefore, under the same conditions, the higher the $\mathrm{w}-\mathrm{b}$ ratio, the more serious the $\mathrm{F}-\mathrm{T}$ damage. Moreover, $\mathrm{w}-\mathrm{b}$ ratio had a great influence on pore structure (30). Furthermore, high $\mathrm{w}-\mathrm{b}$ ratio led to poor compactness and internal bond of concrete. Thus, the ratio had a significant effect on the frost resistance of concrete.

Specimens in group $\mathrm{C}(\mathrm{C})$ and $\mathrm{C}(\mathrm{E})$ were selected to illustrate the influence of $U V$ radiation on the frost resistance of concrete. Figures 3(c) and 3(j) show the specimen deterioration after 50 cycles. The surface damage of group $\mathrm{C}(\mathrm{E})$ was more serious than that of group $\mathrm{C}(\mathrm{C})$ after $50 \mathrm{~F}-\mathrm{T}$ cycles. However, the surface damage of both groups gradually increased with the number of F-T cycles. Moreover, the difference in surface damage between groups $C(E)$ and $\mathrm{C}(\mathrm{C})$ was gradually reduced. After $150 \mathrm{~F}-\mathrm{T}$ cycles, the surface damage of the two groups were the same (Figures 3(d) and 3(k)), which could be attributed to the UV radiation only affecting a certain depth of concrete surface. Therefore, in the early stage of $\mathrm{F}-\mathrm{T}$ cycle test, specimens in group $\mathrm{C}(\mathrm{E})$ more likely suffered from F-T damage, and the surface damage of group $\mathrm{C}(\mathrm{E})$ was more serious than that of group C(C). As the number of F-T cycles increased, the surface mortar of specimens showed gradual stripping. Furthermore, the effect of UV radiation gradually disappeared. Afterwards, the damage of the two groups gradually approached the same level.

\subsection{Mass loss ratio}

Figure 4 shows the concrete deterioration in the mass loss ratio under F-T cycles. As shown in Figure 4, the testing data reveal that mass loss was strongly reduced and was consistent as the $\mathrm{w}-\mathrm{b}$ ratio decreased. In the three control groups, the mass loss ratio of group $\mathrm{A}(\mathrm{C})$ was the lowest, whereas that of group $\mathrm{C}(\mathrm{C})$ was the highest. Specimens in group $\mathrm{A}(\mathrm{C})$ began to lose mass after $100 \mathrm{~F}-\mathrm{T}$ cycles, whereas the mass loss ratios of specimens in groups $\mathrm{B}(\mathrm{C})$ and $\mathrm{C}(\mathrm{C})$ were $0.56 \%$ and $1.21 \%$, respectively. After $200 \mathrm{~F}-\mathrm{T}$ cycles, the mass loss ratios of specimens in groups $\mathrm{A}(\mathrm{C}), \mathrm{B}(\mathrm{C})$ and $\mathrm{C}(\mathrm{C})$ were $0.58 \%$, $1.72 \%$ and $3.56 \%$, respectively. When subjected to $275 \mathrm{~F}-\mathrm{T}$ cycles, the mass loss ratios of specimens in groups $\mathrm{A}(\mathrm{C}), \mathrm{B}(\mathrm{C})$ and $\mathrm{C}(\mathrm{C})$ were $0.88 \%, 2.88 \%$ and $4.72 \%$, respectively. Thus, under the same F-T cycles, high $\mathrm{w}-\mathrm{b}$ ratio resulted in high mass loss and

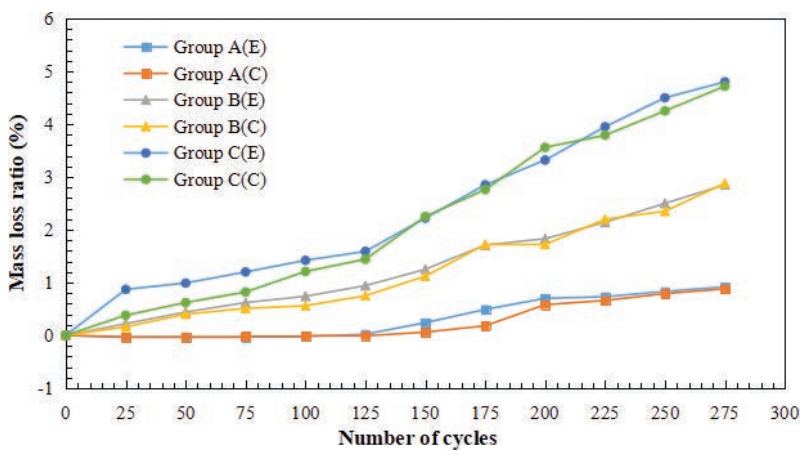

Figure 4. Mass loss ratio of concrete under F-T cycles.

poor frost resistance of concrete. This result was consistent with the conclusions in Section 3.1.

The mass of specimens in group A increased at the beginning of the F-T test because these specimens had good frost resistance, and the surface damage was extremely low that it was negligible. In addition, a certain level of moisture could be absorbed into the specimens in the early $\mathrm{F}-\mathrm{T}$ test. Therefore, the mass of specimens in group A slightly increased initially and then decreased. In each group, the mass loss ratio gradually increased with the number of F-T cycles. Nevertheless, the increase rate of the mass loss ratio in different groups had minimal difference. The increase rate in the mass loss ratio of the specimens in group $\mathrm{C}(\mathrm{C})$ initially accelerated and then decelerated. However, the mass loss ratio of the specimens in group $\mathrm{C}(\mathrm{E})$ initially reached a high level and then slowly increased during the early stage and quickly increased in later F-T cycles. This occurrence might be due to the UV radiation affecting the surface mortar of the concrete specimens in group $\mathrm{C}$, thereby resulting in $\mathrm{F}-\mathrm{T}$ damage at the early stage of $\mathrm{F}-\mathrm{T}$ cycles.

For the mass loss ratio of groups $\mathrm{A}(\mathrm{E})$ and $\mathrm{A}(\mathrm{C})$, no evident difference was found before $125 \mathrm{~F}-\mathrm{T}$ cycles and after $200 \mathrm{~F}-\mathrm{T}$ cycles. From 125 to 200 F-T cycles, the mass loss ratio of group $\mathrm{A}(\mathrm{E})$ was higher than that of group $\mathrm{A}(\mathrm{C})$. The mass loss ratio of group $\mathrm{B}(\mathrm{E})$ was also higher than that of $\mathrm{B}(\mathrm{C})$ before $175 \mathrm{~F}-\mathrm{T}$ cycles and was the same after 175 $\mathrm{F}-\mathrm{T}$ cycles. In addition, the mass loss ratio of group $\mathrm{C}(\mathrm{E})$ was higher than that of $\mathrm{C}(\mathrm{C})$ before $150 \mathrm{~F}-\mathrm{T}$ cycles and was the same after $150 \mathrm{~F}-\mathrm{T}$ cycles. The largest difference of mass loss ratio between experimental and control groups was $0.49 \%$ in group C at $50 \mathrm{~F}-\mathrm{T}$ cycles. The effect of UV radiation on the frost resistance of high $\mathrm{w}-\mathrm{b}$ ratio concrete was reflected in the early stage of $\mathrm{F}-\mathrm{T}$ test, whereas that of low $\mathrm{w}-\mathrm{b}$ ratio concrete was reflected after a certain number of F-T cycles. This result might be due to the adverse effect of UV radiation on the concrete surface, which accelerated the surface mortar stripping at the beginning of $\mathrm{F}-\mathrm{T}$ damage. The F-T 
damage of high $\mathrm{w}-\mathrm{b}$ ratio group occurred later than the low $\mathrm{w}-\mathrm{b}$ ratio group.

Table 3 shows the results of two-way ANOVA of mass loss ratio. The analytical method mentioned in Section 2.4 demonstrated that UV radiation statistically significantly affected the mass loss ratio $(p<$ $0.05)$. The mass loss ratio primarily reflects the surface damage. Therefore, UV radiation significantly affected the concrete surface. As discussed in Section 3.5 , the microstructure of the surface mortar was analysed by SEM to verify the reliability of the analysis.

\subsection{RDME}

Figure 5 illustrates the concrete deterioration in the RDME under F-T cycles. From the figure, the testing data indicated that RDME slightly decreased with the increase of $\mathrm{w}-\mathrm{b}$ ratio. In the three control groups, the RDME of group $\mathrm{C}(\mathrm{C})$ was the lowest, whereas that of group $\mathrm{A}(\mathrm{C})$ was the highest. After 25 $\mathrm{F}-\mathrm{T}$ cycles, the RDME of specimens in group $\mathrm{A}(\mathrm{C})$ only began to decrease, whereas that of specimens in group C(C) had already decreased to $92.25 \%$. When subjected to $150 \mathrm{~F}-\mathrm{T}$ cycles, the values of RDME of specimens in groups $\mathrm{A}(\mathrm{C}), \mathrm{B}(\mathrm{C})$ and $\mathrm{C}(\mathrm{C})$ were $90.41 \%, 84.9 \%$ and $84.32 \%$, respectively. After 275 $\mathrm{F}-\mathrm{T}$ cycles, the values of RDME of specimens in groups $\mathrm{A}(\mathrm{C}), \mathrm{B}(\mathrm{C})$ and $\mathrm{C}(\mathrm{C})$ were $84.5 \%, 75.32 \%$ and $67.32 \%$, respectively. In summary, under the same $\mathrm{F}-\mathrm{T}$ cycles, high $\mathrm{w}-\mathrm{b}$ ratio resulted in low RDME and poor frost resistance of concrete. This result was consistent with the previously mentioned conclusions.

In each group, RDME gradually decreased with the increase in the number of $\mathrm{F}-\mathrm{T}$ cycles. At the beginning of the $\mathrm{F}-\mathrm{T}$ test $(0-50$ cycles), the reduction

TABLE 3. Results of ANOVA of mass loss ratio

\begin{tabular}{|c|c|c|c|c|c|c|}
\hline Group & Source of variation & Sum of squares & DF & Mean square & $F$ & $P$ \\
\hline \multirow[t]{4}{*}{ A } & UV radiation & 0.0234 & 1 & 0.0234 & 4.89 & 0.0491 \\
\hline & F-T cycles & 3.0385 & 11 & 0.2762 & 57.64 & 0 \\
\hline & Error & 0.0527 & 11 & 0.0048 & & \\
\hline & Total & 3.1146 & 23 & & & \\
\hline \multirow[t]{4}{*}{ B } & UV radiation & 0.0315 & 1 & 0.0315 & 8.80 & 0.0128 \\
\hline & F-T cycles & 19.3928 & 11 & 1.7630 & 492.05 & 0 \\
\hline & Error & 0.0394 & 11 & 0.0036 & & \\
\hline & Total & 19.4638 & 23 & & & \\
\hline \multirow[t]{4}{*}{$\mathrm{C}$} & UV radiation & 0.1520 & 1 & 0.1520 & 7.51 & 0.0192 \\
\hline & $\mathrm{F}-\mathrm{T}$ cycles & 55.8053 & 11 & 5.0732 & 250.76 & 0 \\
\hline & Error & 0.2225 & 11 & 0.0202 & & \\
\hline & Total & 56.1799 & 23 & & & \\
\hline
\end{tabular}

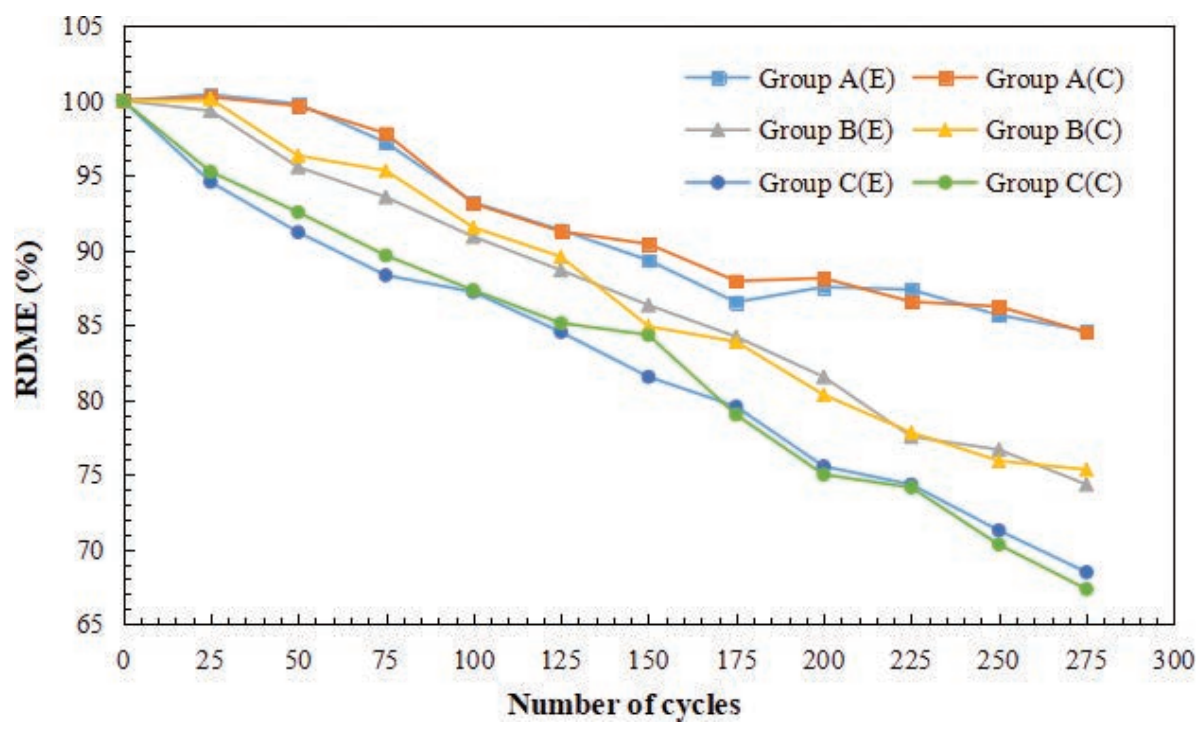

Figure 5. RDME of concrete under F-T cycles. 
rate of the decreased RDME in group $\mathrm{C}$ was faster than that in groups $\mathrm{B}$ and $\mathrm{C}$. However, no difference was evident in the reduction rates among the groups after $75 \mathrm{~F}-\mathrm{T}$ cycles. For the RDME of groups A(E) and $\mathrm{A}(\mathrm{C})$, no difference was observed in the early and late stages of the $\mathrm{F}-\mathrm{T}$ test. The RDME of group $\mathrm{A}(\mathrm{C})$ was also slightly higher than that of group $A(E)$ in the middle stages. For groups $\mathrm{B}$ and $\mathrm{C}$, the RDME of the control group was higher than that of the experimental group in the early stage of $\mathrm{F}-\mathrm{T}$ test. The result was the same for the later stage. The largest difference of RDME between experimental and control groups was $2.8 \%$ in group $\mathrm{C}$ at $150 \mathrm{~F}-\mathrm{T}$ cycles.

Table 4 shows the results of two-way ANOVA of RDME. As shown in the table, UV radiation statistically insignificantly changed the RDME of concrete $(p>0.05)$ because the RDME is a measurement of the inner compact degree $(31,32)$. Moreover, given that the specimens were UV-treated after they were moulded, only the surface of specimens was exposed to UV radiation. As a result, UV radiation had difficulty in affecting the interior of specimens. Ultimately, UV radiation insignificantly affected the RDME. The results of RDME were consistent with those of previous works $(33,34)$. However, these previous studies have not considered the effect of UV radiation.

\subsection{Flexural strength}

Figure 6 demonstrates the flexural strength of the concrete after 275 F-T cycles. As shown in Figure 6, no evident difference was observed in the flexural strength between the control and experimental groups after $275 \mathrm{~F}-\mathrm{T}$ cycles. The largest difference of flexural strength between control and experimental groups was $0.04 \mathrm{MPa}$. Therefore, UV radiation showed no evident effect on the flexural strength of concrete after $\mathrm{F}-\mathrm{T}$ cycles.

TABLE 4. Results of ANOVA of RDME

\begin{tabular}{|c|c|c|c|c|c|c|}
\hline Group & Source of variation & Sum of squares & DF & Mean square & $F$ & $P$ \\
\hline \multirow[t]{4}{*}{ A } & UV radiation & 0.3432 & 1 & 0.3432 & 1.77 & 0.2104 \\
\hline & $\mathrm{F}-\mathrm{T}$ cycles & 775.4268 & 11 & 70.4933 & 363.46 & 0 \\
\hline & Error & 2.1334 & 11 & 0.1939 & & \\
\hline & Total & 777.9035 & 23 & & & \\
\hline \multirow[t]{4}{*}{ B } & UV radiation & 0.2440 & 1 & 0.2440 & 0.52 & 0.4848 \\
\hline & F-T cycles & 1767.4110 & 11 & 160.6737 & 344.20 & 0 \\
\hline & Error & 5.1349 & 11 & 0.4668 & & \\
\hline & Total & 1772.7899 & 23 & & & \\
\hline \multirow[t]{4}{*}{$\mathrm{C}$} & UV radiation & 0.5046 & 1 & 0.5046 & 0.79 & 0.3932 \\
\hline & $\mathrm{F}-\mathrm{T}$ cycles & 2190.1053 & 11 & 199.1046 & 311.66 & 0 \\
\hline & Error & 7.0273 & 11 & 0.6388 & & \\
\hline & Total & 2197.6822 & 23 & & & \\
\hline
\end{tabular}

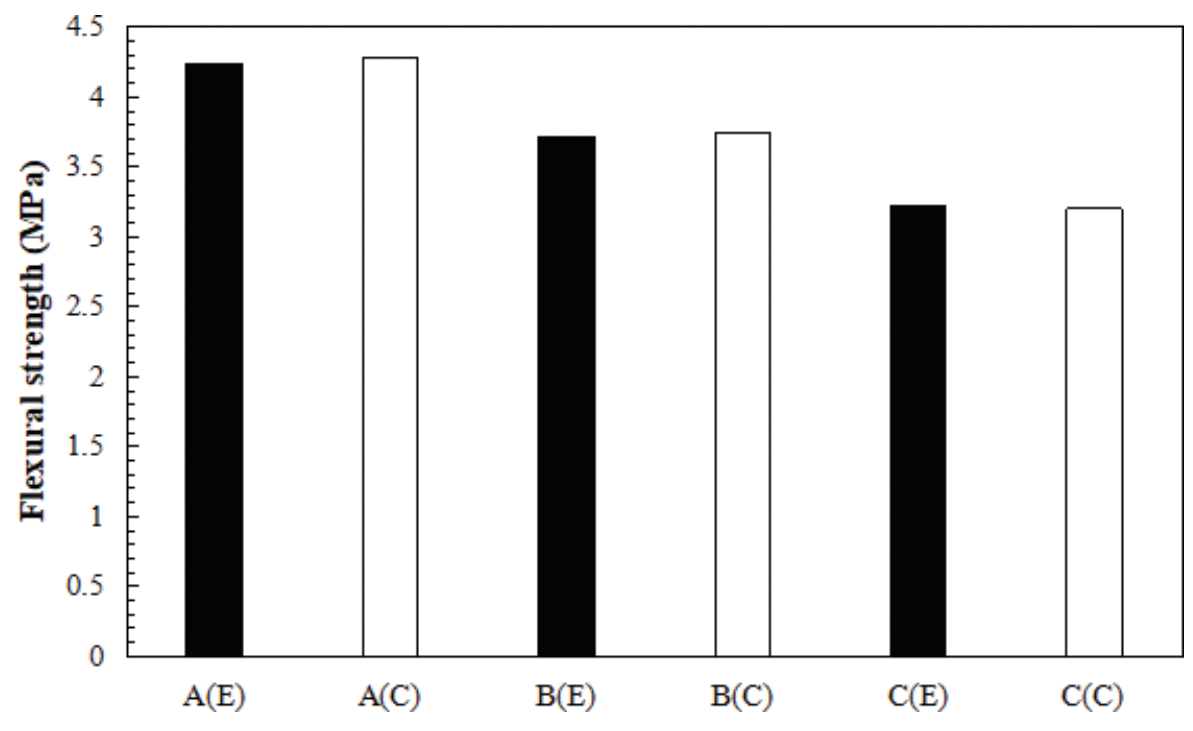

FIgURE 6. Flexural strength of concrete after 275 F-T cycles. 
Damage behaviours of concrete and prediction models under the joint effect of freeze-thaw attack and ultraviolet radiation $\bullet 9$

TABLE 5. Results of ANOVA of flexural strength

\begin{tabular}{llccrr}
\hline $\begin{array}{l}\text { Source of } \\
\text { variation }\end{array}$ & $\begin{array}{l}\text { Sum of } \\
\text { squares }\end{array}$ & DF & $\begin{array}{l}\text { Mean } \\
\text { square }\end{array}$ & \multicolumn{1}{c}{$F$} & \multicolumn{1}{c}{$P$} \\
\hline UV radiation & 0.00004 & 1 & 0.00004 & 0.81 & 0.4639 \\
w-b ratio & 1.1025 & 2 & 0.55125 & 1066.94 & 0.0009 \\
Error & 0.00103 & 2 & 0.00052 & & \\
Total & 1.10395 & 5 & & & \\
\hline
\end{tabular}

Table 5 presents the results of two-way ANOVA of the flexural strength of concrete. As shown in the table, the effect of UV radiation on flexural strength was insignificant $(p>0.05)$.

\subsection{Microstructure characterisation}

Figure 7 presents the specimen microstructure in group B characterised by SEM. The concrete
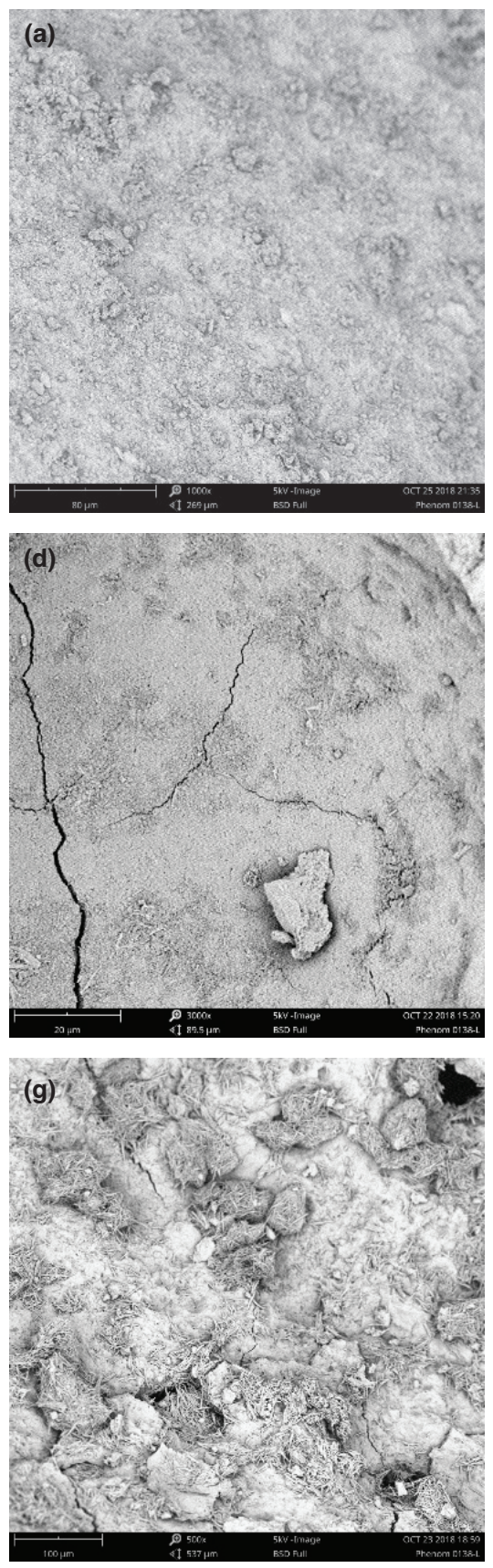
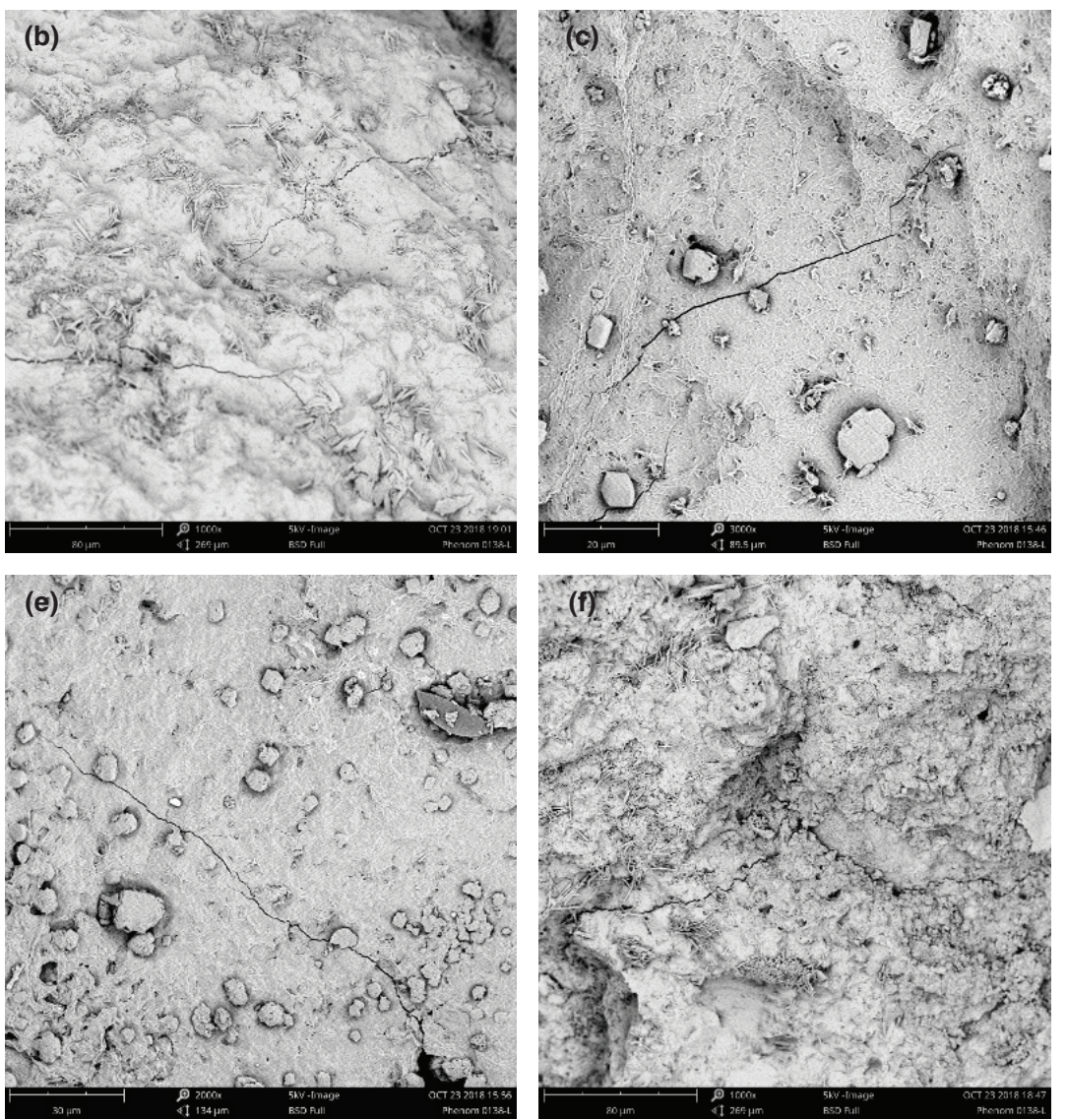

FIGURE 7. SEM micro-photographs of specimens. (a) Surface mortar of B(C) before test (b) Surface mortar of B(C) after $100 \mathrm{~F}-\mathrm{T}$ cycles (c) Internal mortar of B(C) after $100 \mathrm{~F}-\mathrm{T}$ cycles (d) Surface mortar of B(E) after 100 F-T cycles (e) Internal mortar of B(E) after 100 F-T cycles (f) Surface mortar of B(C) after 275 F-T cycles (g) Surface mortar of B(E) after 275 F-T cycles. 
specimens without damage history (i.e. Figure 7(a)) were smooth and dense, whereas varying degrees of damage were observed on concrete after UV radiation and F-T cycles (i.e. Figures 7 (b)-7(g)). As the number of $\mathrm{F}-\mathrm{T}$ cycles increased, the surface of mortar was no longer smooth. Moreover, the number of cracks and pores increased. This result explains the damage degree increment and RDME reduction. For example, Figures 7(f) and 7(g) show that specimens after $275 \mathrm{~F}-\mathrm{T}$ cycles seemed rough and uneven, accompanied by several microcracks and pores.

As shown in Figures 7(b)-7(e), no evident difference was found between Figures 7(c) and 7(e), whereas slight differences were observed between Figures 7(b) and 7(d). In Figure 7(b), the particle fraction of concrete was more uniform and compact than that in Figure 7(d) because UV radiation had certain hindrances to the hydration reaction. The comparison of Figures 7(b) and 7(d) demonstrated that the damage degree of surface mortar of the specimens exposed to UV radiation followed by $100 \mathrm{~F}-\mathrm{T}$ cycles was slightly higher than that of the specimens subjected to $100 \mathrm{~F}-\mathrm{T}$ cycles without UV radiation. UV radiation could only affect the surface mortar of specimens, and this phenomenon was consistent with the results of mass loss ratio and RDME. No difference was observed between Figures $7(\mathrm{f})$ and $7(\mathrm{~g})$. Thus, the effect of UV radiation on concrete could be ignored at $275 \mathrm{~F}-\mathrm{T}$ cycles because of the increased damage degree of concrete with the increased number of $\mathrm{F}-\mathrm{T}$ cycles. Moreover, the effect of UV radiation on concrete could eventually be negligible.

\subsection{F-T damage model considering UV radiation}

On the basis of damage theory, various microcracks and microdefects in concrete structures can be regarded as a continuous distribution of damage field in a material. RDME is easy to measure and analyse in F-T cycle test. Moreover, RDME is an important index to describe the internal damage of concrete materials (35). In addition, RDME can be used to analyse the internal damage degree of concrete materials quantitatively. Therefore, damage degree is defined as follows:

$$
D_{n}=1-\frac{E_{n}}{E_{0}}
$$

where $D_{n}$ is the damage degree after $n \mathrm{~F}-\mathrm{T}$ cycles, $E_{n}$ is the dynamic modulus of elasticity after $n \mathrm{~F}-\mathrm{T}$ cycles and $E_{0}$ is the initial dynamic modulus of elasticity.

Table 6 shows that the F-T damage model of each group was obtained by linear regression analysis of the experimental data. Moreover, the model fitted by each group was in good agreement with the experimental results. In addition, the coefficient of determination of each model was all above 0.92 . On this basis, the models and experimental results had a high-fitting accuracy. Therefore, the damage model of F-T cycles was reasonable for the experimental results. Figure 8 the comparison of the fitting curves of the groups with the experimental data. The damage degree of group A initially accelerated and then decelerated as the number of F-T cycles increased, whereas that of group $\mathrm{C}$ rapidly developed at the beginning of the test. The reason for this difference might be that the surface of specimens in group $\mathrm{C}$ was significantly affected by UV radiation. Furthermore, the surface mortar was rapidly damaged at the beginning of $\mathrm{F}-\mathrm{T}$ cycles.

\section{CONCLUSIONS}

This study experimentally investigated the mass loss ratio, RDME, flexural strength and microstructure of concrete under the joint effect of UV radiation and F-T attack. The following conclusions were drawn on the basis of the results.

1. The mass loss increased and RDME decreased with the increase of $\mathrm{F}-\mathrm{T}$ cycles. In addition, the $\mathrm{w}-\mathrm{b}$ ratio had significant influence on mass loss ratio, RDME and flexural strength. Moreover, the high w-b ratio caused high mass loss ratio, low RDME and low flexural strength.

2. For concrete with high $\mathrm{w}-\mathrm{b}$ ratio, the effect of UV radiation on the mass loss ratio was reflected in the early stage of $\mathrm{F}-\mathrm{T}$ test, whereas that of low $\mathrm{w}-\mathrm{b}$ ratio concrete was reflected after a certain number of F-T cycles. However, the effect of UV radiation on the RDME and flexural strength of concrete was insignificant.

3. SEM analysis on the microstructure of the surface mortar of the specimens showed that UV radiation could make the surface mortar suffer further serious $\mathrm{F}-\mathrm{T}$ damage in the early stage of F-T test. However, UV radiation had no effect on internal mortar. In addition, the results of microscopic analysis obtained from SEM were consistent with the macroscopic results.

TABLE 6. Damage models and coefficients of determination

\begin{tabular}{lcc}
\hline Group & Damage model & $\begin{array}{c}\text { Coefficient } \\
\text { of determination } \mathbf{R}^{2}\end{array}$ \\
\hline $\mathrm{A}(\mathrm{E})$ & $D=0.0006 x-0.0076$ & 0.9281 \\
$\mathrm{~A}(\mathrm{C})$ & $D=0.0006 x-0.0087$ & 0.9469 \\
$\mathrm{~B}(\mathrm{E})$ & $D=0.001 x-0.0075$ & 0.9953 \\
$\mathrm{~B}(\mathrm{C})$ & $D=0.001 x-0.0146$ & 0.9863 \\
$\mathrm{C}(\mathrm{E})$ & $D=0.0011 x+0.0226$ & 0.9901 \\
$\mathrm{C}(\mathrm{C})$ & $D=0.0011 x+0.0106$ & 0.9903 \\
\hline
\end{tabular}





FIGURE 8. Comparisons of experimental values of damage degree with its prediction models. (a) Group A(E) (b) Group A(C) (c) Group B(E) (d) Group B(C) (e) Group C(E) (f) Group C(C)

4. Prediction models of the damage degree of concrete under the joint effect of UV radiation and F-T attack were proposed on the basis of linear regression. The comparison results indicated that the prediction values had good consistency with the experimental values. Therefore, the models could be used to predict the damage degree of concrete under the joint effect of $\mathrm{UV}$ radiation and $\mathrm{F}-\mathrm{T}$ attack.

\section{ACKNOWLEDGEMENTS}

This study has been carried out with the financially support of the National Natural Science Foundation of China (51679197). 


\section{REFERENCES}

1. Tang, S.W.; Yao, Y.; Andrade, C.; Li, Z.J. (2015) Recent durability studies on concrete structure. Cem. Concr. Res. 78, 143-154. https://doi.org/10.1016/j.cemconres.2015.05.021.

2. Zhang, X.H.; Wang, L.; Zhang, J.R. (2017) Mechanical behavior and chloride penetration of high strength concrete under freeze-thaw attack. Cold Reg. Sci. Tech. 142, 17-24. https://doi.org/10.1016/j.coldregions.2017.07.004.

3. Hanjari, K.Z.; Utgenannt, P.; Lundgren, K. (2011) Experimental study of the material and bond properties of frost-damaged concrete. Cem. Concr. Res. 41 [3], 244-254. https://doi.org/10.1016/j.cemconres.2010.11.007.

4. Ebrahimi, K.; Daiezadeh M.J. Zakertabrizi, M. Zahmatkesh, F.; Korayem, A.H. (2018) A review of the impact of micro- and nanoparticles on freeze-thaw durability of hardened concrete: Mechanism perspective. Constr. Build. Mater. 186, 1105-1113. https://doi.org/10.1016/j. conbuildmat.2018.08.029.

5. Litvan, G.G. (1972) Phase transitions of adsorbates: IV, mechanism of frost action in hardened cement paste. J. Am. Ceram. Soc. 55 [1], 38-42. https://doi. org/10.1111/j.1151-2916.1972.tb13393.x

6. Collins. A. (1944) The destruction of concrete by frost. J. Inst. Civ. Eng. 23 [1], 29-41. https://doi.org/10.1680/ ijoti.1944.14086.

7. Qin, X.C.; Meng, S.P.; Cao, D.F.; Tu, Y.M.; Sabourova, N.; Grip, N.; Ohlsson, U.; Blanksvärd, T.; Sas, G.; Elfgren, L. (2016) Evaluation of freeze-thaw damage on concrete material and prestressed concrete specimens. Constr. Build. Mater. 125, 892-904. https://doi.org/10.1016/j. conbuildmat.2016.08.098

8. Tuyan, M.; Mardani-Aghabaglou, A.; Ramyar, K. (2014) Freeze-thaw resistance, mechanical and transport properties of self-consolidating concrete incorporating coarse recycled concrete aggregate. Mater. Des. 53, 983-991. https://doi.org/10.1016/j.matdes.2013.07.100.

9. Sun, Z.H.; Scherer, G.W. (2010) Effect of air voids on salt scaling and internal freezing. Cem. Concr. Res. 40 [2], 260-270. https://doi.org/10.1016/j.cemconres.2009.09.027.

10. Cavdar, A. (2014) Investigation of freeze-thaw effects on mechanical properties of fiber reinforced cement mortars. Compos. Pt. B-Eng. 58, 463-472. https://doi.org/10.1016/j. compositesb.2013.11.013.

11. Li, Y.; Wang, R.J.; Li, S.Y. Zhao, Y; Qin, Y. (2018) Resistance of recycled aggregate concrete containing low- and highvolume fly ash against the combined action of freeze-thaw cycles and sulfate attack. Constr. Build. Mater. 166, 23-34. https://doi.org/10.1016/j.conbuildmat.2018.01.084

12. Wang, D.Z.; Zhou, X.M.; Meng, Y.F.; Chen, Z. (2017) Durability of concrete containing fly ash and silica fume against combined freezing-thawing and sulfate attack. Constr. Build. Mater. 147, 398-406. https://doi. org/10.1016/j.conbuildmat.2017.04.172

13. Yang, H.Q.; Shen, X.M.; Rao, M.J.; Li, X.; Wang, X.D. (2015) Influence of alternation of sulfate attack and freezethaw on microstructure of concrete. Adv. Mater. Sci. Eng. 1, 1-7. https://doi.org/10.1155/2015/859069.

14. Wang, J.B.; Niu, D.T. (2016) Influence of freeze-thaw cycles and sulfate corrosion resistance on shotcrete with and without steel fiber. Constr. Build. Mater. 122, 628-636. https://doi.org/10.1016/j.conbuildmat.2016.06.100.

15. Piasta, W.; Marczewska, J.; Jaworska, M. (2015) Durability of air entrained cement mortars under combined sulphate and freeze-thaw attack. Procedia Eng. 108, 55-62. https:// doi.org/10.1016/j.proeng.2015.06.119.

16. Tian, J.; Wang, W.W.; Du, Y.F. (2016) Damage behaviors of self-compacting concrete and prediction model under coupling effect of salt freeze-thaw and flexural load. Constr. Build. Mater. 119, 241-250. https://doi.org/10.1016/j. conbuildmat.2016.05.073.

17. Kosior-Kazberuk, M.; Berkowski, P. (2017) Surface scaling resistance of concrete subjected to freeze-thaw cycles and sustained load. Procedia Eng. 172, 513-520. https://doi. org/10.1016/j.proeng.2017.02.060.
18. Diao, B.; Sun, Y.; Cheng, S.H.; Eng., P.; Ye, Y.H. (2011) Effects of mixed corrosion, freeze-thaw cycles, and persistent loads on behavior of reinforced concrete beams. J. Cold Reg. Eng. 25 [1], 37-52. https://doi.org/10.1061/ (ASCE)CR.1943-5495.0000019.

19. Enfedaque, A.; Romero, H.L.; Gálvez, J.C. (2014) Fracture energy evolution of two concretes resistant to the action of freeze-thaw cycles. Mater. Constr. 64 [313], 60-71. https:// doi.org/10.3989/mc.2014.00813.

20. Lu, J.Z.; Zhu, K.F.; Tian, L.Z.; Guo, L. (2017) Dynamic compressive strength of concrete damaged by fatigue loading and freeze-thaw cycling. Constr. Build. Mater. 152,847-855. https://doi.org/10.1016/j.conbuildmat.2017. 07.046 .

21. Wang, Z.D.; Zeng, Q.; Wang, L.; Yao, Y.; Li, K.F. (2014) Corrosion of rebar in concrete under cyclic freezethaw and chloride salt action. Constr. Build. Mater. $53,40-47$. https://doi.org/10.1016/j.conbuildmat.2013. 11.063 .

22. Jacobsen, S.; Marchand, J.; Boisvert, L. (1996) Effect of cracking and healing on chloride transport in OPC concrete. Cem. Concr. Res. 26 [6], 869-881. https://doi. org/10.1016/0008-8846(96)00072-5.

23. Zhang, P.; Cong, Y.; Vogel, M.; Liu, Z.L.; Müller, H.S.; Zhu, Y.G.; Zhao, T.J. (2017) Steel reinforcement corrosion in concrete under combined actions: The role of freeze-thaw cycles, chloride ingress, and surface impregnation. Constr. Build. Mater. 148, 113-121. https://doi. org/10.1016/j.conbuildmat.2017.05.078.

24. Kuosa, H. Ferreira, R.M.; Holt, E.; Leivo, M.; Vesikari, E. (2014) Effect of coupled deterioration by freeze-thaw, carbonation and chlorides on concrete service life. Cem. Concr. Compos. 47, 32-40. https://doi.org/10.1016/j. cemconcomp.2013.10.008

25. He, Z.; Tang, S.W.; Zhao, G.S.; Chen, E. (2016) Comparison of three and one dimensional attacks of freeze-thaw and carbonation for concrete samples. Constr. Build. Mater. 127, 596-606. https://doi.org/10.1016/j. conbuildmat.2016.09.069.

26. Liu, F; You, Z.P; Yang, X: Wang, H.N. (2018) Macromicro degradation process of fly ash concrete under alternation of freeze-thaw cycles subjected to sulfate and carbonation. Constr. Build. Mater. 181, 369-380. https:// doi.org/10.1016/j.conbuildmat.2018.06.037.

27. Ge, X.; Ge, Y.; Du, Y. B.; Cai, X. P. (2017) Effect of low air pressure on mechanical properties and shrinkage of concrete. Mag. Concr. Res. 70 [18], 1-12. https://doi. org/10.1680/jmacr.17.00305.

28. Güllü, H. (2015) On the viscous behavior of cement mixtures with clay, sand, lime and bottom ash for jet grouting. Constr. Build. Mater. 93, 891-910. https://doi.org/10.1016/j. conbuildmat.2015.05.072

29. Cui, W.; Huang, J.Y.; Song, H.F.; Xiao, M. (2017) Development of two new anti-washout grouting materials using multi-way ANOVA in conjunction with grey relational analysis. Constr. Build. Mater. 156, 184-198. https:// doi.org/10.1016/j.conbuildmat.2017.08.126.

30. Li, C.Z.; Jiang, L.H.; Xu, N.; Jiang S.B. (2018) Pore structure and permeability of concrete with high volume of limestone powder addition. Powder Technol. 338, 416- 424. https://doi.org/10.1016/j.powtec.2018.07.054.

31. Ma, H.X.; Yu, H.F.; Li, C.; Tan, Y.S.; Cao, W.T.; Da, Bo. (2018) Freeze-thaw damage to high-performance concrete with synthetic fibre and fly ash due to ethylene glycol deicer. Constr. Build. Mater. 187, 197-204. https://doi. org/10.1016/j.conbuildmat.2018.07.189.

32. Wongpa, J.; Kiattikomol, K.; Jaturapitakkul, C.; Chindaprasirt, P. (2010) Compressive strength, modulus of elasticity, and water permeability of inorganic polymer concrete. Mater. Des. 31 [10], 4748-4754. https://doi. org/10.1016/j.matdes.2010.05.012

33. Jiang, L.; Niu, D.T.; Yuan, L.D.; Fei, Q.N. (2015) Durability of concrete under sulfate attack exposed to freeze-thaw cycles. Cold Reg. Sci. Tech. 112, 112-117. https://doi.org/10.1016/j.coldregions.2014.12.006. 
Damage behaviours of concrete and prediction models under the joint effect of freeze-thaw attack and ultraviolet radiation $\bullet 13$

34. Wu, H.; Liu, Z.; Sun, B.B.; Yin, J. (2016) Experimental investigation on freeze-thaw durability of Portland cement pervious concrete (PCPC). Constr. Build. Mater. 117, 63-71. https://doi.org/10.1016/j.conbuildmat.2016. 04.130 .
35. Yu, H.F.; Ma, H.X.; Yan, K. (2017) An equation for determining freeze-thaw fatigue damage in concrete and a model for predicting the service life. Constr. Build. Mater. 137, 104-116. https://doi.org/10.1016/j.conbuildmat. 2017.01.042. 